\title{
THE RUSSIAN OIL EXPORTS VIA THE BALTIC SEA - DO OIL SHIPMENTS THROUGH THE EU'S INNER SEA BRING RUSSIA CLOSER TO THE EU OR BRING THEM APART?
}

\author{
Kari Liuhto \\ The Research Group for Russian and East European Business, Lappeenranta University of Technology, \\ PO. Box 20, FIN-53851 Lappeenranta, Finland
}

Received: 3 January, 2003

\begin{abstract}
The paper deals with Russian oil exports policy. Russia's oil reserves, oil production and main export routs have been scrutinized and evaluated.
\end{abstract}

Keywords: Russia's oil, oil exports, oil reserves, oil production, oil exports, oil shipments via Baltic sea

\section{Russia's Oil Reserves in an International Comparison}

The EU has only a per cent of the world's oil reservoirs. Despite its non-existent oil reserves, the Union uses nearly a fifth of the globe's oil. The 2004-enlargement will not increase the Union's oil reserves but rather its consumption, i.e. our oil import dependence will grow. The EU's dependence on the imported oil is at the moment over 70\%. Russia is the EU's second most important external source of oil after Norway. Currently, more than $15 \%$ of the EU's total oil imports arrive from Russia and her proportion will grow after the next enlargement.

The USA's oil balance is even more unsustainable than that of the EU. Although the USA has only $3 \%$ of the world reserves, she consumes over a quarter of the globe's oil, making the US economy very dependent on imports. The US economy would swallow in 4-5 years all the country's own reserves, if she would not receive oil from elsewhere. Though the USA is highly dependent on imported oil, one should not forget that the USA has relatively substantial oil basins relatively near-by. Mexico's reserves, for instance, are almost as large as those of the USA. The American continent as a whole holds some $15 \%$ of the global oil reserves, i.e. some three times that of Russia.

China, with a quarter of the globe's population, consumes at the moment only $7 \%$ of the world oil, which is slightly less than the Japanese consumption. China's consumption will grow, however, along with the progress in the industrialisation of the country. It has been forecasted that by 2020, China would have become the second largest oil consumer after the USA. In order to secure the country's foreign supplies, Chinese companies have conducted energy-related investments in over 20 countries, including Russia. The majority of China's oil imports come from Middle East, but China diversifies her oil imports, and thus, eyes on Russian oil with a special interest.

The world's proven oil reserves are heavily concentrated in Middle East. Five Middle East countries account for almost two-thirds of the global reservoirs: Saudi Arabia (25\%), Iraq (11\%), United Arab Emir- 
Table 1. Russia's Oil Reserves, Production and Consumption in an International Comparison

\begin{tabular}{llll}
\hline \multicolumn{1}{c}{ Reserves } & \multicolumn{1}{c}{ Production } & \multicolumn{1}{c}{ Consumption } \\
\hline Russia & $\begin{array}{l}\text { 5\% of the world total } \\
\text { (7th after Saudi Arabia, Iraq, } \\
\text { United Arab Emirates, } \\
\text { Kuwait, Iran, and Venezuela) }\end{array}$ & $\begin{array}{l}\text { 10\% of the world total } \\
\text { (3rd after Saudi Arabia and } \\
\text { USA) }\end{array}$ & $\begin{array}{l}\text { 4\% of the world total } \\
\text { (5th after USA, Japan, } \\
\text { China, and Germany) }\end{array}$ \\
USA & $3 \%$ of the world total & $10 \%$ of the world total & $26 \%$ of the world total \\
China & $2 \%$ of the world total & $1 \%$ of the world total & $7 \%$ of the world total \\
EU15 & $1 \%$ of the world total & $4 \%$ of the world total & $18 \%$ of the world total \\
EU25 & $1 \%$ of the world total & $4 \%$ of the world total & $20 \%$ of the world total \\
Middle East & $65 \%$ of the world total & $30 \%$ of the world total & $6 \%$ of the world total \\
Americas & $15 \%$ of the world total & $28 \%$ of the world total & $37 \%$ of the world total \\
OECD & $8 \%$ of the world total & $28 \%$ of the world total & $62 \%$ of the world total \\
OPEC & $78 \%$ of the world total & $41 \%$ of the world total & No data available \\
\hline
\end{tabular}

Source: [1]; own calculations.

ates $(9 \%)$, Kuwait $(9 \%)$, and Iran $(9 \%)$. These five aforementioned countries are in fact the biggest oil possessors in the globe. A calculation exercise shows that with Iraq's proven oil reservoirs alone the USA could meet her total oil consumption for 17 years, if the US consumption will remain at the current level [1].

Venezuela and Russia have the largest oil reservoirs outside Middle East. Venezuela possesses some 7\% and Russia nearly $5 \%$ of the world's oil. Russia's proven oil reserves are 6700 million tonnes $(\mathrm{mt})$. Russia produces $10 \%$ of the globe's oil production, even if her own oil consumption is only $4 \%$. This means in practice that Russia exports a significant stake of her oil production, approximately every second oil barrel produced in the country goes abroad (Table 1).

Some three-quarters of the Russian oil reserves are located in Western Siberia, in the Tjumen region. The Tjumen region belongs administratively into the Urals Federal District. Even if Tjumen holds the majority of the country's oil, highly potential reserves have also been discovered in the northern parts of European Russia. Russia's main reservoirs close to the EU are located in the Timan-Pechora area (Table 2).

The Russian oil majors hold the lion's share of the Russian oil reservoirs. TNK possesses the biggest oil reservoirs in Russia, followed by Lukoil, Yukos, Rosneft, and Surgutneftegaz. Together these five oil majors have oil, amounting to almost $13000 \mathrm{mt}$, which is double the amount [1] argues that the whole
Table 2. The Location of Russia's Oil Reserves

\begin{tabular}{lc}
\hline North of European Russia & $7.0 \%$ \\
The Northern Caucasus & $0.9 \%$ \\
The Volga region & $6.2 \%$ \\
The Ural Mountains & $8.9 \%$ \\
Western Siberia & $73.4 \%$ \\
Eastern Siberia & $1.6 \%$ \\
The Far East & $1.0 \%$ \\
The Continental Shelf & $0.8 \%$ \\
\hline
\end{tabular}

Source: [2].

Russian Federation possesses. The explanation for the difference is the different classification method of oil reserves, i.e. the Russian method includes also reservoirs which are unlikely to be commercially exploited (Table 3).

\section{Russia's Oil Production}

Russia's oil industry accounted for approximately $90 \%$ of the entire USSR's oil output. Prior to the disintegration of the Soviet Union, the Russian oil production exceeded $500 \mathrm{mt}$. Due to the break up of the socialist system, Russia's production started to decline. Since the year 1999 the production has however revived. In 1999, Russia's production was roughly 300 $\mathrm{mt}$, and the Russian Energy Ministry expects it to reach almost $400 \mathrm{mt}$ in 2003. It has been projected that 
Table 3. Oil Reserves of Major Russian Oil Corporations in 2000 (mt)

\begin{tabular}{lcc}
\hline Company* & Oil reserves & $\begin{array}{c}\text { State/regional } \\
\text { ownership }\end{array}$ \\
\hline Lukoil** & 3344 & $14 \%(8 \%)$ \\
Yukos *** & 2607 & $0 \%$ \\
Surgutneftegaz & 1504 & $1 \%$ \\
TNK **** & 3707 & $0 \%$ \\
Tatneft & 841 & $33 \%$ \\
Sibneft $* * *$ & 753 & $0 \%$ \\
Rosneft & 1573 & $100 \%$ \\
Bashneft & 365 & $65 \%$ \\
Slavneft** & 286 & $75 \%(0 \%)$ \\
\hline
\end{tabular}

* All data applying to companies' operations inside the Russian Federation i.e. foreign activities are excluded from the figures.

** The state sold some $6 \%$ of Lukoil and Slavneft was privatised in 2002.

*** Yukos and Sibneft informed about their merger in April 2003.

**** TNK merged with British Petroleum (BP) at the beginning of 2003.

Sources: [3]; [4]; [5].

at the end of this decade the oil production would reach almost at the same level where it used be before the disintegration of the Soviet Union (Table 4).

A clear trend in Russia over recent decades has been the deteriorating structure of the reserve base. Over $70 \%$ of the reserves currently being operated yield low flow rates, such that their development is only marginally commercial. A decade ago wells yielding flow rates of up to 25 tonnes per day accounted for nearly $55 \%$ of total reserves in development. At present, 55\% of oil reserves in development now yield flow rates of 10 tonnes per day or less. The average flow per well has dropped from 11.6 tonnes in 1990 to 7.7 tonnes in 1998.

The depletion of existing oil fields in Western Siberia and the fact that oil production is exceeding the rate of discovery of new reserves by a significant margin have raised fears that Russia's current oil boom will be followed by a sharp decline in the next decade. In order to increase oil production, large amounts of capital will be required to develop new fields and to extend the life of existing oil fields with exhausted and low-yield reserves. Currently, 82 fields account for over $60 \%$ of Russia's remaining reserves.

The overwhelming majority of oil is produced in the Urals Federal District, particularly in the Tjumen region. This region dominates the Russian oil production, covering two-thirds of the oil output. The Volga Federal District accounts for almost a quarter of the production, Tatarstan being its oil centre, though significant amounts of oil is produced also in Bashkortostan, Orenburg, Perm, and Samara. The North West Federal District is responsible for $4 \%$ of the Russian Federations oil output, Komi being its regional oil centre. The three aforementioned federal districts form over $90 \%$ of the federation's total output (Table 5).

The Timan-Pechora Basin contains many already discovered, but so far underdeveloped fields. Only about $10 \%$ of the initial endowment has already been extracted. A total of 190 oil and gas fields have been discovered in the basin, while around 30 are currently being worked. When production in Timan-Pechora gathers full speed, it really places North West Russia in the country's oil map [3].

Over 100 companies produce oil in Russia, but despite their large number, the production is practically in hands of 10 vertically integrated companies ${ }^{1}$. The production volume of 10 biggest companies is around $350 \mathrm{mt}$, i.e. they account for some $90 \%$ of the oil production in Russia. Two biggest alone, namely Lukoil and Yukos, cover some $40 \%$. Though Lukoil still is Russia's biggest oil producer, it would not surprise if Yukos would claim this title already in this year or

\footnotetext{
${ }^{1}$ Already in the next decade, the number of the big players has probably decreased to a half, what it is at the moment. The April 2003 merger between two big oil companies, Yukos and Sibneft, is just a sign of such a consolidation process in this industry.
}

Table 4. The Development of Oil Production and Refining in Russia (mt)

\begin{tabular}{|c|c|c|c|c|c|c|c|c|c|c|c|c|c|}
\hline & 1990 & 1995 & 1996 & 1997 & 1998 & 1999 & 2000 & 2001 & 2002 & 2003 & 2004 & 2005 & 2010 \\
\hline Production & $515.9 *$ & 306.8 & 301.2 & 305.6 & 303.3 & 305.0 & 323.5 & 348.1 & 377.0 & 397.0 & 419.0 & 448.0 & 510.0 \\
\hline Refining & n.d. & 174.0 & 199.2 & 197.2 & 163.3 & 174.2 & 179.0 & 186.0 & 182.0 & 195.0 & 200.0 & 206.0 & 214.0 \\
\hline $\begin{array}{l}\text { Refining - } \\
\text { production ratio }\end{array}$ & - & $57 \%$ & $66 \%$ & $65 \%$ & $54 \%$ & $57 \%$ & $55 \%$ & $53 \%$ & $48 \%$ & $49 \%$ & $48 \%$ & $46 \%$ & $42 \%$ \\
\hline
\end{tabular}


Table 5. The Development of Oil Production in the Russian Regions (1000 tonnes)

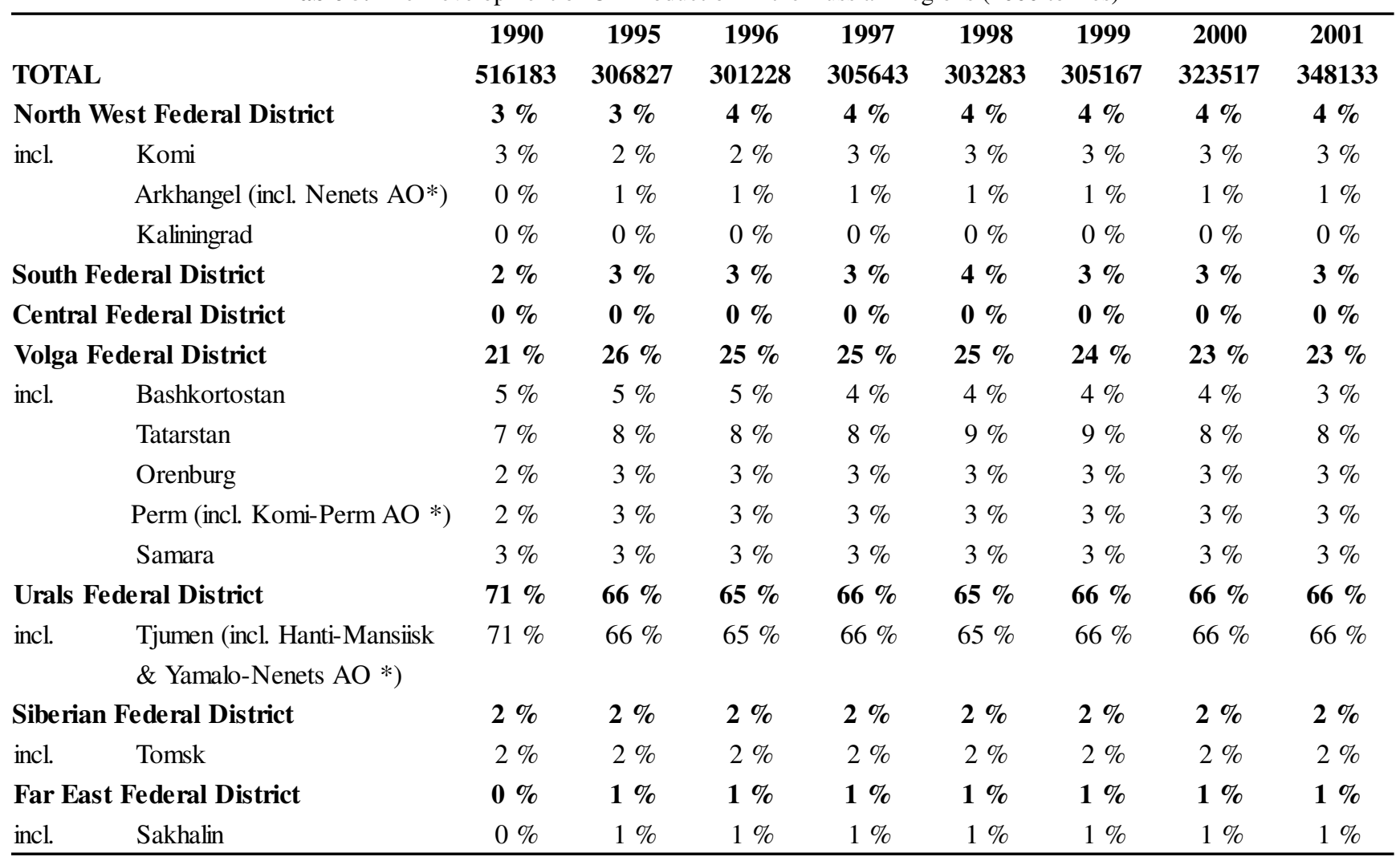

* $\mathrm{AO}=$ autonomous area. Source: [8].

Table 6. Crude Production of 10 Major Russian Oil Corporations (mt)

\begin{tabular}{lccccccc}
\hline & $\mathbf{1 9 9 6}$ & $\mathbf{1 9 9 7}$ & $\mathbf{1 9 9 8}$ & $\mathbf{1 9 9 9}$ & $\mathbf{2 0 0 0}$ & $\mathbf{2 0 0 1}$ & $\mathbf{2 0 0 2}$ \\
Lukoil & 50.9 & 53.4 & 53.7 & 53.4 & 69.1 & 73.0 & 78.2 \\
Yukos & 35.3 & 35.6 & 34.1 & 34.2 & 49.5 & 58.1 & 72.8 \\
Surgutnefteg. & 33.3 & 33.9 & 35.2 & 37.6 & 40.6 & 44.0 & 49.2 \\
TNK & 21.5 & 21.0 & 19.7 & 20.1 & 28.6 & 40.6 & 38.0 \\
Sibneft & 18.7 & 18.2 & 17.3 & 16.3 & 17.2 & 20.6 & 26.3 \\
Tatneft & 23.7 & 23.2 & 24.4 & 24.4 & 24.3 & 24.6 & 24.2 \\
Slavneft & 12.9 & 12.3 & 11.8 & 11.9 & 12.3 & 13.5 & 16.2 \\
Rosneft & 13.0 & 13.4 & 12.6 & 12.6 & 13.5 & 14.9 & 16.0 \\
Sidanko & 20.8 & 20.3 & 19.9 & 19.6 & 13.0 & $\ldots$ & 16.0 \\
Bashneft & 16.3 & 15.4 & 12.9 & 12.3 & 11.9 & $\ldots$ & $\ldots$ \\
\hline
\end{tabular}

Source: [10].

2004 at latest. Note that Yukos has doubled its production volume during the past 3 years (Table 6).

Oil business in Russia is not completely in hands of domestic companies but some foreign oil corporations have started their activities in the Russian market. In 2000 , foreign-owned companies accounted together 6$7 \%$ of Russia's oil production ${ }^{2}$. The foreign direct

2 "Many partners defined as foreign firms are in fact Russian-owned companies registered in foreign countries to benefit from the special privileges granted to joint ventures with foreign partners. It is estimated that JVS with 'genuine' foreign partners produced about nine mt in 1999, less than half officially reported total output for all JVs" [5]. investment (FDI) to the fuel and energy sector amounted to over $\$ 440$ million, or some $10 \%$ of total FDI inflow ( [14]; [4] ). The main genuine foreign actors in the Russian oil business are (in an alphabetical order): Agip, BP, British Gas, ChevronTexaco, Conoco, ExxonMobil, Neste Oy, Norsk Hydro, McDermott, Mitsubishi, Mitsui, Royal Dutch/Shell, Statoil, and TotalFinaElf [9].

BP has conducted the biggest single investment in Russia, worth almost $\$ 7$ bn. In the beginning of 2003, $\mathrm{BP}$ and Alfa-Access/Renova group (AAR) announced the creation of a new company, TNK-BP. This entity is to be owned equally by these two parties. AAR will 
Table 7. Top 10 Net Oil Exporters and Importers in 2000 *

\begin{tabular}{clclc}
\hline Rank & Exporter & Mn tonnes & Importer & Mn tonnes \\
1. & Saudi Arabia & 373 & USA & 531 \\
2. & Russia & $\mathbf{1 9 2}$ & Japan & 261 \\
3. & Venezuela & 152 & Germany & 124 \\
4. & Norway & 151 & Korea & 107 \\
5. & Iran & 130 & France & 90 \\
6. & Iraq & 104 & Italy & 89 \\
7. & Nigeria & 100 & PR of China & 74 \\
8. & United Arab Emirates & 100 & Spain & 71 \\
9. & Kuwait & 88 & India & 67 \\
10. & Mexico & 77 & Chinese Taipei & 45 \\
\end{tabular}

* Includes crude oil and petroleum products. Source: [5].

contribute its oil interests in TNK International, including the stake in RUSIA Petroleum, Sidanko and Rospan to the new company, while BP will donate its stakes in Sidanko and RUSIA Petroleum, as well as its Moscow retail network and interest in Sakhalin projects. AAR will also receive payment from BP of $\$ 3$ billion in cash and $\$ 1.25$ billion in BP shares a year for three years once the deal has been completed. This new business entity will be the third largest oil producer in Russia after Lukoil and Yukos. As a result, some $30 \%$ of BP's net reserves and $13 \%$ of its net production will reside in Russia. This new venture is the largest commitment ever by a multinational oil company in Russia and clearly very positive for the future of the country's investment climate.

\section{Russia's Oil Exports and Main Export Routes}

\subsection{Oil Exports}

Crude oil and oil products account for some $40 \%$ of Russia's total exports, and hence, oil is an essential source of the budget revenue for Russia [11]. Though the Russian Federation does not belong into the OPEC, the country is important player in the international oil business. Russia is the biggest net exporter of oil after Saudi Arabia. Russia, Norway and Mexico are the only non-OPEC countries among the 10 largest net exporters of the world (Table 7).

In 2000, Russia exported some $145 \mathrm{mt}$ of crude oil and the remaining $50 \mathrm{mt}$ is oil products. Since the year 2000 , both the exports of crude and oil products have grown. The Russian crude exports have doubled since 1996 and are estimated to reach $200 \mathrm{mt}$ in 2003. It has been forecasted that the export growth will remain high, and the Russian Ministry of Energy predicts that the country's crude exports will climb to almost 300 $\mathrm{mt}$ in 2010 .

Exports of crude are increasing constrained by transport bottlenecks, making Russian oil majors rely more on exports of oil products in the future. Unlike crude, oil products can be economically transported to ports by rail, making their transport less of a problem. However, at present the problem with Russian exports of oil products is its generally low quality. Russia still lags behind in producing low sulphur motor fuels, which will be compulsory in the European Union by 2005, and still exports a lot of fuel oil (oil product with relatively low value-added), the demand for which is declining.

In this context, one should not forget that in order to reach such an ambitious export goal, large investments should be conducted to the oil logistics, i.e. new oil pipes, pumping stations, storage tanks, and oil terminals should be constructed. As the state-company, Transneft ${ }^{3}$, monopolising the country's crude pipes does not possess sufficient financial reserves, the liberalisation of the state monopoly would be needed i.e. private oil companies should be allowed to build and own pipes ${ }^{4}$. Otherwise, the 2010-export goal of 300 mt cannot simply be reached (Table 8).

\footnotetext{
3 Transneft, a state controlled company, is responsible for almost $50000 \mathrm{~km}$ of trunk oil pipelines. The pipeline network currently interconnects with 16 foreign countries, including Azerbaijan, Belarus, Kazakhstan, Latvia, Lithuania, Turkmenistan, Ukraine, and Uzbekistan in the former Soviet Union, and Croatia, the Czech Republic, Germany, Hungary, Poland, Serbia, Slovakia, and Slovenia. In the forthcoming years, the system will probably spread into China. Transneft transports over $90 \%$ of oil produced in Russia.

4 "In accordance with effective law on pipeline transport, privately owned crude oil pipelines cannot exist in the Russian Federation" [12].
} 
Table 8. The Development of the Russian Crude Oil Exports (mt)

\begin{tabular}{lcccccccccccc}
\hline & $\mathbf{1 9 9 5}$ & $\mathbf{1 9 9 6}$ & $\mathbf{1 9 9 7}$ & $\mathbf{1 9 9 8}$ & $\mathbf{1 9 9 9}$ & $\mathbf{2 0 0 0}$ & $\mathbf{2 0 0 1}$ & $\mathbf{2 0 0 2}$ & $\mathbf{2 0 0 3}$ & $\mathbf{2 0 0 4}$ & $\mathbf{2 0 0 5}$ & $\mathbf{2 0 1 0}$ \\
Exports & 132.8 & 102.0 & 108.4 & 140.0 & 130.8 & 144.5 & 162.1 & 195.0 & 202.0 & 219.0 & 242.0 & 296.0 \\
Growth & n.d. & $-23 \%$ & $6 \%$ & $29 \%$ & $-7 \%$ & $10 \%$ & $12 \%$ & $20 \%$ & $4 \%$ & $8 \%$ & $11 \%$ & - \\
Exp. / Prod. & $43 \%$ & $34 \%$ & $35 \%$ & $46 \%$ & $43 \%$ & $45 \%$ & $47 \%$ & $52 \%$ & $51 \%$ & $52 \%$ & $54 \%$ & $58 \%$ \\
\hline
\end{tabular}

* Include exports of crude oil. Source: [6], for reference see [7]; author's calculation.

"By 2010 oil intended for export will exceed export capacity in Russia by some 80 million tonnes per year. Pipeline projects currently underway, such as the Baltic Pipeline System and Caspian Pipeline Consortium will do little to alleviate this export capacity deficit. Existing Russian terminals on the Baltic and Black Sea coast are capable of loading tankers of up to only $140000 d w t$ due to restrictions in effect in the Turkish and Danish sea straits. For that reason, up to 80 million tonnes of oil will 'get stuck' on Russia's domestic market by 2010" [7].

The share of the USA in Russia's oil exports is at the moment marginal, less than $1 \%$, but it may grow substantially in the middle term. "Of the 9.1 million of barrels of oil daily imported by the USA at present, hardly any crude is supplied by Russian companies. With the Murmansk project up and running, by 2010 the share of Russian suppliers on the American market may grow to $13 \%$. This estimate appears quite feasible in view of the fact that oil production in several traditional key areas supplying the USA, such as the Gulf of Mexico and the North Sea, is expected to slump over 2002-2010. Russia may fill in the gap on the US market. However, should the USA succeed with what it plans in Iraq (toppling leader Saddam Hussein), then Iraq rather than Russia will flood USA with cheap oil" [7].

[9] indicates that the transportation and production costs of delivering Russian oil to the USA are considerably higher than those of Middle East producers, making it unlikely that Russian oil will replace Middle East oil on the US market. Besides, one should not forget that supplying a tenth of the US oil imports would mean in practice selling over $50 \mathrm{mt}$ of oil annually.

\subsection{Main Export Routes}

In $2002,55 \%$ of the Russian oil was exported by sea, $40 \%$ through the Druzhba pipeline, and some 5\% by railway. Besides own oil exports, a considerable amount of other countries' oil, nearly $20 \mathrm{mt}$, transited through Russia. The overwhelming majority of transit oil originates from Kazakhstan, over three-quarters.

\section{Main Oil Export-linked Pipelines}

The main export route of the Russian oil to the West is the Druzhba trunk line, with a nominal $60-\mathrm{mt}$ capacity. The pipe traverses Belarus before splitting into northern and southern routes. The northern link runs from Russia via Belarus and Poland to Germany. The southern line crosses northern Ukraine and goes through Hungary and Slovakia ending in the Czech Republic. The northern pipe is now fully used, while the southern arm of the trunk has still available capacity, and therefore, Russia aims at exploiting the available capacity by integrating the southern arm of Druzhba with the Adria pipeline.

The integration of the Druzhba and Adria pipes in Croatia and the reversal of Omisalj-Sisak linkage provide Russian oil exporters direct access to the Adriatic Sea, where tankers can be loaded at the deep water port of Omisalj, allowing them to bypass the increasingly crowded Bosporos Straits. The deepness of the port allows up to $500000 \mathrm{dwt}$-tankers to collect oil from the port, which in turn makes the exports to the USA economically feasible alternative. Another advantage of Omisalj is the shorter maritime travel to US ports. It is about $600 \mathrm{~km}$ shorter than from Ceyhan, and roughly $1000 \mathrm{~km}$ shorter than Novorossiysk. The only other option that promises lower transportation costs for Russian crude to West European countries and the USA is the Murmansk port, which is to be constructed by the end of the decade.

Yukos has signed a $\$ 20 \mathrm{mn}$ agreement with a Croatian oil transport company Jadranski Naftovod (Janaf) to accomplish this integration. However, the first loading of Russian crude at Omisalj could be delayed to 2004 or beyond, since the Croatian firm has failed to start to work on the integration, as the estimated costs of the reversing pipe have multiplied from $\$ 20 \mathrm{mn}$ to $\$ 80 \mathrm{mn}$. It is expected that the Druzhba-Adria pipe would handle some $5 \mathrm{mt}$ when it will be opened. According to optimistic plans, its capacity might be increased to $10-15 \mathrm{mt}$ by 2013 .

The Baltic Pipeline System (BPS) involves the 450km pipe from Kharyaga (Nenets Autonomous District, Arkhangel region), to Usa (the Komi Republic), the 
Usa-Ukhta, Ukhta-Yaroslav, and Yaroslav-Kirishi pipelines, and the pipe from Kirishi to Primorsk. The BPS is fully owned and operated by Transneft. The first stage of the BPS was completed by December 2001, and the building of the second stage has started. The second stage is to be completed by the end of 2003 . The completion of the second stage will increase the BPS' capacity to $18 \mathrm{mt}$ from the current $12 \mathrm{mt}$. The capacity may grow to $30 \mathrm{mt}$ by the mid-2004 and even 50-70 $\mathrm{mt}$ by the end of this decade. The BPS delivers oil mainly from Timan-Pechora and Western Siberia, though it may also transport oil from Kazakhstan.

In September 2001, Russia finished SukhodolnayaRodionovskaya pipeline. This $250-\mathrm{km}$ pipe allows Russian oil companies to deliver oil to Novorossiysk oil export terminal without using the pipe section in the Ukrainian territory. Hence, the Russian companies may avoid Ukraine's high transit fees and illegal tapping from the pipe. The throughput capacity of the pipe is around $16-25 \mathrm{mt}$.

Besides the aforementioned pipes, Kazakh oil transit Russia via the Caspian Pipeline Consortium (CPC). Over $1500-\mathrm{km}$ CPC pipe started to operate at the end of 2001. An international consortium runs CPC instead of Transneft. Though Transneft does not control the CPC, one should keep in mind that Russia is the largest owner in the consortium, possessing almost a quarter. The CPC delivers oil from large Kazakh oil field, Tengiz to Novorossiysk, the Russian oil terminal on the Black Sea. The initial capacity of the pipe is nearly $30 \mathrm{mt}$, with throughput possibly increasing to over 60 mt by 2015 .

CPC is not the only example of Kazakh oil transiting Russia. Kazakh oil may also be moved via the AtyrauSamara pipe, to be pumped further to the Druzhba line or the BPS. Smaller amounts of Kazakh oil are also shipped to Azerbaijan, where it can be put through Baku-Novorossiysk pipe. However, the amount is relatively insignificant, roughly $2.5 \mathrm{mt}$. Azerbaijan may also offer other routes, such as Baku-Supsa and BakuTbilisi-Ceyhan connections. Baku-Supsa collects reportedly lower transit ( $\$ 2$ per barrel) fees than BakuNovorossiysk ( $\$ 3$ per barrel), and on contrary, BakuTbilisi-Ceyhan higher fees (\$ 4 per barrel).

Besides these Western routes, Russia will pipe her oil to the East in the future. Russia signed a co-operation agreement with Japan on January 2003 regarding building almost $4000-\mathrm{km}$ pipeline from Angarsk in Eastern Siberia to the Russian Pacific port of Nahodka. The estimated cost of the building this $45-\mathrm{mt}$ pipe is around \$ 5-6 bn. Besides the construction of the pipe, the project envisages an oil-loading berth at
Perevoznaya Buhta, with deep-water capacity for tankers to load up to 300000 tonnes of oil. Transneft is the controlling operator of this project.

This project is a competitor to a plan to build a smaller 20-mt crude pipe from Angarsk to Daqing in Manchuria. This pipe would be less than half the length of that to Nahodka, $1700 \mathrm{~km}$. The construction of this connection would require some $\$ 2.2 \mathrm{bn}$. This project is designed by private Russian oil major, Yukos. At present, Yukos is supplying China with a mere $1.5 \mathrm{mt}$ of crude via rail, but it has recently agreed on deliveries of $18 \mathrm{mt}$ by 2005 and over $25 \mathrm{mt}$ by 2010 .

The Russian Ministry of Energy came in February 2003 with a proposal to bring together these two projects i.e. the Ministry has proposed that the Angarsk-Daqing and Angarsk-Nahodka pipelines will be merged and staged into a single project. The Russian Minister of Energy informed that the pipeline merger represented the best interest of Russia. The plan is to lay a single Angarsk-Daqing pipeline via Chita, with a branch line running to Daqing. In fact, the Angarsk-Daqing leg will be laid first, with the extension to Nahodka coming later. The route to China should be operational by 2005 . The Russian government will probably make the final decision on the pipeline routing in May 2003.

The Sakhalin-1, a group operated by ExxonMobil, favours 250-km-underwater pipeline. The consortium members aim at exporting oil across the Tatar Straits to DeKastri, on the Russian mainland, where an existing tanker terminal could be expanded to handle exports to Asia. The pipe will be reasonably cheap to be built, but off-takers will have to contend with ice for several months a year. The consortium is planning for annual capacity of both terminal and pipe to reach between 12 to $15 \mathrm{mt}$. The Sakhalin-1 group indicates its export route will be cheaper than that of Sakhalin2 , but the group acknowledges that exports will not begin before 2005 .

Sakhalin-2, a consortium led by RD Shell, has plans to export oil to Japan, South Korea, and Taiwan by building nearly $800-\mathrm{km}$ oil pipe down the length of Sakhalin Island to the ice-free port of Prigorodnoye. This plan is expensive but it allows year-round oil exports.

Summa summarum, the Druzhba pipe is Russia's main export pipe. In addition, to this trunk line one can name the Baltic Pipeline System and the goal to integrate Druzhba and Adria pipes. One should not forget the eastern pipes, which allows Russia to sell more oil to the East, but nevertheless do not provide a genu- 
ine solution for the country's oil export bottlenecks. Perhaps, the most appropriate way to solve the export bottlenecks in the middle term would be the construction of the pipe to Murmansk and a large oil terminal there. In addition to building new pipe routes, the importance of the investments into the maintenance and repair should be kept in mind as the existing pipe network and other logistical facilities are ageing. In $2000,73 \%$ of Russian oil pipelines were over 20 years old.

\section{Major Oil Export Ports}

The port of Novorossiysk on the Black Sea has traditionally been Russia's largest oil export terminal. Roughly 1/4 of Russian crude was exported via this port in 2000. However, the port's capacity has been increased due to the fact that the Caspian Pipeline Consortium's pipe started to operate at the end of 2001. This pipe delivers the Kazakh oil from the large Tengiz oil field to Novorossiysk. Also small amounts of the Azeri oil end in the port of Novorossiysk. In the future, some shipments of Turkmen oil may go to this port, but so far the disagreement between Russia and Turkmenistan has prevent oil transit.

The ports on the Baltic Sea are gaining importance in Russia's oil exports. The Latvian port of Ventspils has traditionally been the major oil terminal on the Baltic Sea. The position of Ventspils has been challenged by the Tallinn port, which has increased its oil exports extremely fast, though oil has to be delivered by rail, whereas the pipe connects the Ventspils terminal. Transneft's oil embargo, which will probably last until the end of the year, has made the Ventpils port's position very difficult ${ }^{5}$. Thirdly, the Russian oil companies are building oil terminals in the Russian territory of the Baltic Sea, for instance in Primorsk.

Primorsk is the biggest oil terminal on the Russian territory of the Baltic Sea. In 2002, Primorsk served 135 tankers and shipped some $12 \mathrm{mt}$ of crude oil. After the completion of the second pipe into the port in 2003, the capacity will jump into $18 \mathrm{mt}$. It has been suggested that the terminal will be attached to an oil product pipeline with a planned capacity of $10 \mathrm{mt}$ per year by 2005 . According to some plans, Primorsk's

\footnotetext{
5 Transneft's oil embargo towards Ventspils stem from the fact that the privatisation of Ventspils is to take place by the end of 2003 i.e. the Russian oil companies are eager to acquire the $43 \%$-stake under the privatisation. Russia's four biggest oil producers - Lukoil, Yukos, TNK, and Surgutneftegaz - have asked the Russian government to lift the block, as the blockade has increased oil supply in Russia and dropped the domestic oil price.
}

capacity will increase into 50-70 $\mathrm{mt}$ by the end of this decade. Some plans are indicating even higher amounts, up to $90 \mathrm{mt}$, but the author is not confident whether these plans are realistic, especially taking into consideration the possible opening of the giant Murmansk port.

In addition to Primorsk, one should not forget the oil transportation via Petersburg Oil Port. Roughly 7$11 \mathrm{mt}$ oil products went through this port 2002, and its capacity is expected to grow if the port starts to handle also crude oil.

The Bukhta Batareinaya oil terminal, located to the West of St. Petersburg, is to be completed by the end of 2004. Its planned capacity is some $15 \mathrm{mt}$ per year. Oil is transported to this terminal by rail. Surgutneftegaz will operate this port.

Lukoil invests some $\$ 300 \mathrm{mn}$ in Vysotsk to construct an oil port there. The terminal with the capacity of $5 \mathrm{mt}$ is to be commissioned by November of 2003 and by the end of 2004 the port's capacity is to be lifted to nearly $11 \mathrm{mt}$. However, this plan might be difficult to achieve because of capacity limitations on the rail line serving the terminal. When completed the terminal allows to handle tankers up to $80000 \mathrm{dwt}$.

Also a small oil facility has been planned in Vyborg, with an initial capacity lower than $1 \mathrm{mt}$. In November 2000, Lukoil opened a new oil terminal in Kaliningrad. This terminal is estimated to be capable of handling up to $5 \mathrm{mt}$ of oil annually (Table 9).

One of the biggest decision to influence oil transportation via the Baltic Sea is the plan to construct the Murmansk oil terminal. The consortium of four Russian oil majors, Lukoil, Yukos, TNK, and Sibneft plans to build oil pipe from Western Siberia to Murmansk. The investment required for the financing this project is \$ 3.4-4.5 bn, depending whether the pipe either cross or bypass the White Sea. Lukoil and Yukos are to cover some two-thirds of the project financing.

The Murmansk port will have several advantages. First, it will have a large capacity, 60-120 mt. Second, it will provide an ice-free sea around the year, a competitive advantage compared with the ports located on the eastern parts of the Baltic Sea. Third, a sheltered harbour and unique depths of the Kola Bay will allow to load 300000 -dwt tankers, which is 3 times the bigger than the maximum tanker size in the Russian ports on the Baltic Sea. Fourth, it is economically feasible transport route. Transporting a tonne of oil via Western Siberia-Murmansk-USA route will cost a total of $\$ 24.00$ to ship, whereas the transportation of the similar amount via Western Siberia-Druzhba pipe- 
Table 9. Some Oil Terminals in the Russia Territory of the Baltic Sea Rim ${ }^{6}$

\begin{tabular}{lcl}
\hline & Actual capacity & Planned capacity \\
Primorsk & $12 \mathrm{mt}$ & $18 \mathrm{mt}$ (up to 50-60 mt by the end of the decade) \\
Petersburg & $7-11 \mathrm{mt}$ & $15 \mathrm{mt}$ (extension open) \\
Buktha Baternaya & $0 \mathrm{mt}$ & $6-15 \mathrm{mt}$ (by the end of 2004) \\
Vysotsk & $0 \mathrm{mt}$ & $5-11 \mathrm{mt}$ (by the end of 2004) \\
Vyborg & $0 \mathrm{mt}$ & $1 \mathrm{mt}$ (extension open) \\
Kaliningrad & $5 \mathrm{mt}$ & no data \\
\hline
\end{tabular}

line-Adria-USA will cost $\$ 29.50$ and Western Siberia-Caspian Pipeline Consortium-USA \$29.90 to deliver $^{7}$. It has been estimated that the project will begin in 2004 and will be completed by 2007 .

To sum up, while the oil prices are high Russian oil companies has a special incentive to export more oil abroad. The Russian government benefits from high oil prices as the government revenues go up. Russian firms cannot, however, increase their oil exports since the export capacity is almost in a full use. Therefore, additional export infrastructure is needed. The question is more whether the government maintains the control policy or allows private companies to build their own pipes.

The second reason favouring the liberalisation of oil pipelines is the risk involved in financing the pipes i.e. it is not necessarily rational for the Russian government to take an extra investment risk when it is probable that the oil prices will start to decline after the oil exports from Iraq will go up.

Thirdly, allowing private companies to build own pipes does not reduce the state revenues from oil exports, but on contrary, the state will receive more income as exports go up. The question is more how to organise the state control over the private pipes. The state does not have to own every pipeline to be able to collect the oil export tariffs.

The author believes that the Russian state would financially benefit from the liberalisation of its oil pipe policy, which currently reminds more the control policies of the past rather than modern policies, which attracts private investments into the sector and enhance competition in the Russian oil business.

\footnotetext{
${ }^{6}$ One should not forget that some non-Russian ports in the Baltic Sea handle a great amount of the Russian crude oil or oil products.

${ }^{7}$ In comparison, transporting of an oil tonne via BakuTbilisi-Ceyhan-USA and via Persian Gulf-USA costs \$ 31.90 and $\$ 19.50$ respectively [7].
}

\section{Future of Russia's Oil Exports via the Ports in the Baltic Sea}

The oil industry is definitely the backbone of the Russian economy. First of all, oil covers a fifth of Russia's primary energy consumption. Second, oil accounts for almost a tenth of the Russian GDP. Thirdly, oil is an important source of the state's tax revenue. According to [4], "Russian oil companies paid around $\$ 15$ billion in taxes to the federal budget in 2000, accounting for 39\% of total federal budget tax revenues". Oil is important not only for the domestic economy but also for the country's external economy, as it forms over a third of Russia's total export earnings, a tenth of the country's inward FDI stock, and a much bigger stake of the Russian outward investments (Table 10).

Table 10. The Importance of Oil in the Russian Economy

\begin{tabular}{l|c}
\hline Primary energy consumption (2001) & $19 \%$ \\
GDP (2000) & $8 \%$ \\
Federal tax revenues (2000) & $39 \%$ \\
Exports of crude oil and oil products (2002) & $37 \%$ \\
FDI stock - including natural gas (1999) & $11 \%$ \\
\hline
\end{tabular}

Sources: 13]; [4]; [1]; [5]; [11].

Both the Russian government and oil companies have a strong incentive to boost oil sales abroad since the state receives a gargantuan amount of revenues from oil exports and the companies take advantage of higher prices outside Russia. Due to constraints in the oil export logistics, export growth cannot be achieved without heavy investments in new pipelines, pumping stations, storage tanks, and oil terminals. If the oil prices dive, the Russian oil cannot compete with the oil producers in the Gulf of Persia, and hence, the Russian oil players will likely postpone their largescale infrastructure investments.

The USA's position in Iraq will determine the location, where the Russian firms will erect new export facilities, since the USA may decide to abandon her earlier plans to increase oil imports from Russia, and instead, increase imports from Iraq. Should this hap- 
pen, Russia may cancel the building of the Murmansk port and the pipe from Angarsk to Nahodka. If the USA abandons or seriously reduces her plans to import oil from Russia, it is obvious that Russia will target her future oil exports to the EU and China, i.e. Russia will invest in building oil terminals in the Baltic Sea Rim and pipes into China.

It seems that the Baltic Sea Rim will be the dominating region in the Russian oil export policy at least in the middle term, but perhaps also in longer run. It is very likely that the oil terminal capacity in the Russia territory of the Baltic Sea will grow bigger than that of the Black Sea. Moreover, it is likely that the Primorsk port will become the biggest oil terminal around the Baltic Sea, i.e. bigger than any oil port in the Baltic States. Primorsk may even challenge Novorossiysk for the position of the biggest oil terminal in Russia.

It is likely that Russia will continue to reduce her dependency on oil transit via the Baltic States because Transneft is thirsty to get transit fees and port payments currently collected by the Baltic operators and ports. The future philosophy of Russian oil export policy is as follows: oil transit via the Baltic States or any foreign state acts only as additional route for oil exports, which the Russian terminals cannot handle themselves. Therefore, the role of the Baltic ports in the Russian oil export logistics will diminish, when the Murmansk port will be constructed. This will be the case even if Transneft would get control over Ventspils.

Until the Murmansk port is constructed, the oil exports via the Baltic Sea will steadily rise. This in turn, would increase a risk of oil tanker accident. The nations around the Baltic Sea should start together to find a solution to minimise a possibility for oil hazard in the sea, which next year becomes almost completely the inner sea of the EU. Though Russia will remain outside the enlarging Union, Russia should be integrated closer towards the co-operation with the EU, as Russia uses both the Baltic Sea and the Mediterranean Sea as her oil transport corridors to the West. The only effective method to prevent major oil average in the seas washing the EU shores is to integrate Russia closer to the relevant decision-making bodies of the EU.

The EU's decision not to allow the single-hulled tankers to enter the EU harbours after 2010 is a necessary but not a sufficient action without Russia's similar decision, since the EU's decision does not stop hazardous ships to fill their tanks in the Russian ports and sail via the international waters of the Baltic Sea to the ports outside the Union. Moreover, before the decision enters into force in 2010, already a major incidence may have occurred ${ }^{8}$. However, the EU's decision is a good starting point to increase safety of the oil maritime transportation from Russia, since the EU is, nevertheless, the main buyer of Russian oil.

The Baltic Sea is special not only due to its inner sea status but also due to its severe climate. It has been estimated that the entire Baltic Sea freezes twice in a century and the Gulf of Finland in every ten years. The ice coverage lasts normally some six months in the Gulf of Finland, where the oil tankers will mainly load their oil in the future. The harsh climate sets special requirements for the oil tankers, the tanker crew, and service providers. Special climatic conditions demand that both the EU and Russian authorities create a clear and homogeneous regulatory framework to prevent misfit ships or unskilled crew to enter the sea. The authorities could require, for instance, that only tankers with a sufficient ice fortification ${ }^{9}$ would be allowed to enter the Baltic Sea during the winter period and the tanker crew would be required to have a special training certificate to prove their skills in semi-arctic sea conditions.

In addition to the special regulatory framework, also a strict Baltic Sea-wide control mechanism should be created to prevent misuses when the technical qualifications of the tankers and the skills of their crew are assessed. Moreover, the established control mechanism should allow authorities to take harder countermeasures, if they pinpoint ships to have released oily bilge water or other illegal emission to the sea ${ }^{10}$. Currently, punishments are too mild, the evaluation process too long, the burden of proof on the authorities' side, and the Baltic Sea lack uniform practices, which usually make the authorities toothless in the front of the illegally acting tankers. Therefore, I propose that regulations should be made uniform the Baltic Sea-wide, punishments should be several times higher, the system should allow authorities to levy punishment on the spot, and the burden of proof should be on the shipping companies' side.

\footnotetext{
${ }^{8}$ International Maritime Organisation legislation only specifies the phase-out of single-hulled fuel tankers by 2015.

${ }^{9}$ Currently, the classification on the ice fortification is not homogeneous in all the Baltic Sea rim states.

${ }^{10}$ During the open water it is easier to pinpoint tankers' illegal emissions to the water, but during the winter the ice covers effluent until the spring. For instance in the spring 2003, the Finnish authorities collected several tonnes of oil from the sea, believed to have belonged to tankers waiting for the entry to Primorsk. All in all, 344 illegal oil emission were detected in the Baltic Sea in 2002, nearly a quarter of them in Finland's territorial waters.
} 
Besides the regulatory framework and control mechanism, the nations around the Baltic Sea should invest more in upgrading Trans-Baltic ship navigation system ${ }^{11}$. At least two "traffic jam" areas put special pressure on developing the system; 1) the vivid HelsinkiTallinn passenger traffic crossing the East-West route of the oil tankers, and 2) the very narrow strait between Sweden and Denmark ${ }^{12}$.

When creating administrative framework for protecting the Baltic Sea, one should keep in mind three issues. First, the accident avoidance is always less expensive than the damage cleaning. Second, it should not be an insurmountable task to combine Russia's interest of maximising her oil export revenues without compromising environmental safety of the Baltic Sea, since after all the EU countries are the main recipients of the Russian oil flowing via this common European sea. Third, the building of the Murmansk oil terminal is economically and environmentally the most rational alternative, since the Murmansk port is icefree all the year round and can serve 2-3 times bigger tankers than even the largest Russian port in the Baltic Sea.

I am personally convinced that the construction of the Murmansk oil terminal is in long run economically the most feasible option and environmentally the safest way to export Russian oil to the West. Besides, the Murmansk option allows Russia to sell her oil either to the USA or to Europe. The Baltic ports do not contain such a freedom of choice. Should Russia, nevertheless, continue to expand her oil maritime transportation via the Baltic Sea, millions of people living

\footnotetext{
11 The Finnish government has proposed the Russian and the Estonian counterparts that they would create together a common maritime navigation system, called VTMIS. This proposal is a step towards the right direction, but it is utmost necessary to include all the Baltic Sea countries under the same roof to avoid any "black spot" in the Baltic Sea.

12 Even if the strait between Sweden and Denmark is wider than the Bosporus, it is nevertheless only $4 \mathrm{~km}$ wide at its narrowest. The strait depth allows tankers up to 150000 dwt to arrive in the Baltic Sea.

${ }_{13}$ Prestige, a 26-year-old single-hulled tanker, sank nearby the Spanish coast in November 2002.
}

nearby the Baltic Sea hope that the Russian government would stop shipping companies to play the Russian roulette with big bullets, i.e. with $100000 \mathrm{dwt}$ tankers, and possibly repeat the Prestige ${ }^{13}$ accident in the Baltic Sea. Similar incident in the Baltic Sea would definitely not aid to intensify the relations between Russia and the EU, since 8 countries out of $25 \mathrm{EU}$ members can be regarded as the Baltic rim countries.

The Russian oil shipments via the Baltic Sea put the EU-Russian relations into a much more demanding test than the Kaliningrad issue. The outcome of this test will ultimately show whether the Russian oil shipments will bring Russia closer to the EU co-operation or will bring the EU and Russia apart.

\section{References}

1. BP Amoco (2002). BP Statistical Review of World Energy, June 2002, London.

2. Dudarev Grigori \& Zverev Michael (1999). Energy Sector in Russia - Economic and Business Outlook, ETLA Discussion Paper, No. 664, Helsinki.

3. Sagers Matthew J. (2001). Developments in Russian Crude Oil Production in 2000, Post-Soviet Geography and Economics, 42/3, p. 153-201.

4. TD (2001). Oil Sector, May 2001, Troika Dialog, Moscow.

5. IEA (2002b). Russia Energy Survey, International Energy Agency, Paris.

6. The Russian Energy Ministry

7. RPI (2003a). Russian Petroleum Investor 12/2.

8. Concord.

9. Goskomstat (2002). Regioni Rossii, The State Statistical Committee of the Russian Federation, Moscow.

10. EIA (2002). http://www.eia.doe.gov

11. Astrov, 2003.

12. BoF (2003). Idäntalouksien viikko 11/2003, Bank of Finland, Helsinki.

13. RPI (2003b). Russian Petroleum Investor 12/3, Concord. 14. EBRD (2001). Transition Report 2001, London.

15. EIU (2001). Russia Country Profile 2001, The Economist Intelligence Unit, London. 